\title{
Inoculation of cucumber plants with Beauveria bassiana enhances resistance to Aphis gossypii (Hemiptera: Aphididae) and increases aphid susceptibility to pirimicarb
}

\author{
Mohammad hOMAYOONZADEH $^{1}$ (D), Mojtaba ESMAEILY ${ }^{1}$, Khalil TALEBI $^{1}$ (D), Hossein ALLAHYARI ${ }^{1}$ (D), \\ STUART REITZ² (iD) and J.P. MICHAUD ${ }^{3, *}$ (iD \\ ${ }^{1}$ Department of Plant Protection, College of Agriculture and Natural Resources, University of Tehran, 31587-77871, Karaj, Iran; \\ e-mails: homayoonzadeh1371@gmail.com,m_smaily@ut.ac.ir, khtalebi@ut.ac.ir, allahyar@ut.ac.ir \\ 2 Department of Crop and Soil Science, Oregon State University, Ontario, Oregon 97914, USA; \\ e-mail: stuart.reitz@oregonstate.edu \\ ${ }^{3}$ Department of Entomology, Agricultural Research Center-Hays, Kansas State University, Hays, KS 67601, USA; \\ e-mail: jpmi@ksu.edu
}

Key words. Cucumis sativus, detoxifying enzymes, energy reserves, entomopathogenic fungus, herbivore physiology, plant secondary metabolites

\begin{abstract}
The entomopathogen Beauveria bassiana (Bals.) Vuill. (Ascomycota: Hypocreales) can colonize plants endophytically and stimulate the production of secondary plant metabolites with anti-herbivore activities. We assayed the topical virulence of $B$. bassiana to Aphis gossypii Glover (Hemiptera: Aphididae), the effects of cucumber inoculation with this fungus on plant metabolites, and the physiological consequences for aphids that fed on these plants. Assays were conducted with both the commercial formulation of $B$. bassiana, 'Naturalis ${ }^{\circledR}-L^{\prime}$ ', at the recommended concentration of $1.5 \mathrm{ml} / \mathrm{L}$ (yielding a spore concentration of $2.3 \times 10^{7} \mathrm{CFU}$ per $\mathrm{ml}$ ), and with a similar concentration of the isolated fungal strain. Topical application of $0.03 \mathrm{ml}$ of solution per $\mathrm{cm}^{2}$, or $1 \times 10^{3} \mathrm{CFU}$, caused $100 \%$ mortality to $A$. gossypii adults after seven days, whether Naturalis ${ }^{\circledR}-\mathrm{L}$ or the isolate alone was used. The fungus grew endophytically into foliage when sprayed on cucumbers at the 2-leaf stage and concentrations of alkaloids, flavonoids, phenols, hydrogen peroxide, and total chlorophyll were higher than in control plants 28 days after inoculation. Malondialdehyde content, plant growth, and total yield were unaffected by $B$. bassiana inoculation. Aphids fed on $B$. bassiana-inoculated plants for $24 \mathrm{~h}$ had reduced activities of detoxifying enzymes (glutathione-S-transferase, carboxylesterase, and acetylcholinesterase) compared to controls. Activities of digestive enzymes, (lipase, $\alpha$-amylase, $\alpha$-glucosidase, and aminopeptidase) were reduced in aphids from inoculated plants, which exhibited higher activities of superoxide dismutase, ascorbate peroxidase, and phenoloxidase, but lower catalase activity. Energy reserves (lipids, protein, and glycogen) were lower in aphids from inoculated plants, and they exhibited reduced fecundity, longevity, and reproductive periods, and a $50 \%$ reduction in the $\mathrm{LC}_{50}$ of pirimicarb. Thus, in addition to causing direct pathogenicity, inoculation of plants with $B$. bassiana negatively impacted $A$. gossypii physiology and reproductive performance and could usefully complement other strategies for managing cotton aphids on greenhouse cucumber.
\end{abstract}

\section{INTRODUCTION}

The cotton aphid, Aphis gossypii Glover (Hemiptera: Aphididae) is a polyphagous cosmopolitan pest of numerous field and greenhouse crops (Ebert \& Cartwright, 1997). It has the capacity for rapid population growth, causing direct feeding damage to host plants and transmitting various plant viruses (Deguine et al., 2017). Management of cotton aphids has conventionally relied on the use of synthetic insecticides (Kandil et al., 2017), which has resulted in the aphids evolving resistance to various insecticidal modes of action, and generated a need for alternative management tactics (Wang et al., 2007; Carletto et al., 2010).
Entomopathogenic fungi can be useful tools for controlling insect pests and are usually compatible with other biologically-based tactics in integrated pest management programs (Gurulingappa et al., 2011). One of the most effective entomopathogens against $A$. gossypii is Beauveria bassiana (Balsamo) Vuillemin (Ascomycota: Hypocreales) (Loureiro \& Moino, 2006). This entomopathogen can also colonize plants and proliferate as an endophyte (Klieber \& Reineke, 2015; McKinnon et al., 2018). Endophytic fungi occur ubiquitously in plants, often without any adverse effects on them, and may actually improve plant tolerance of abiotic and biotic stresses (Ownley et al., 2008; Mo-

\footnotetext{
* Corresponding author; e-mail: jpmi@ksu.edu
} 
loinyane \& Nchu, 2019). For example, Gonzalez-Mas et al. (2019c) showed that B. bassiana growing endophytically within melon plants caused a slight increase in the fecundity of $A$. gossypii feeding on the plants, but this did not translate into aphid population growth, largely due to fungal-induced aphid mortality that ranged from $38-50 \%$.

Endophytic entomopathogenic fungi may help protect plants against herbivores indirectly via induction of plant defenses, or directly via the production of fungal metabolites with insecticidal properties (Moloinyane \& Nchu, 2019). The principal metabolites typically produced by endophytic entomopathogenic fungi within host plants include alkaloids, flavonoids, and phenolic compounds (Espinoza et al., 2019). Levels of metabolites such as hydrogen peroxide $\left(\mathrm{H}_{2} \mathrm{O}_{2}\right)$, malondialdehyde (MDA) (Heidarvand \& Maali-Amiri, 2013), and total chlorophyll (Croft \& Chen, 2017) are often altered in plants in response to biotic and abiotic stresses and can therefore serve as indicators of plant health. Plant secondary metabolites can affect herbivore physiology via changes in levels of digestive enzymes, antioxidant enzymes (Mardani-Talaee et al., 2016), detoxifying enzymes (Carletto et al., 2010; Homayoonzadeh et al., 2020a), and energy reserves (Sinclair, 2015; Homayoonzadeh et al., 2020b). Ultimately, endophytically-induced changes in host plant physiology can alter herbivores population dynamics, creating potentially useful applications in biological pest control (Zahedi et al., 2019).

We hypothesized that inoculation with $B$. bassiana would alter the physiological status of cucumber plants, and the physiology and life history of cotton aphids that feed on these plants, resulting in reduced aphid fitness. Whereas there exists some background information on how and why endophytic $B$. bassiana might help protect cucumber plants from $A$. gossypii, little is known about how it could affect aphid susceptibility to insecticides via effects on the detoxifying enzymes that are often important in insecticide resistance. Therefore, we also examined how B. bassiana inoculation of cucumber plants would affect the susceptibility of $A$. gossypii to pirimicarb, an aphid-specific insecticide commonly used against this pest in greenhouses.

\section{MATERIALS AND METHODS}

\section{Plants}

Seeds of cucumber, Cucumis sativus, cv. Super N3 (HED, Modesto, CA, USA), were planted and grown in $15 \mathrm{~cm}$ (diam) plastic pots of sterilized soil (autoclaved for $20 \mathrm{~min}$ at $121^{\circ} \mathrm{C}$ and $106 \mathrm{kPa}$ pressure) composed of $1: 1: 2$ cocopeat : peat moss : perlite. Plant were grown in a greenhouse under experimental conditions of $26 \pm 2^{\circ} \mathrm{C}, 16 \mathrm{~L}: 8 \mathrm{D}$ photoperiod, 5100 lux light intensity, and $35-40 \%$ RH. Pots were irrigated to soil capacity once every three days and fertilized once every 7 days with a $1.5 \mathrm{~g} /$ liter solution $(250 \mathrm{ml} / \mathrm{plant})$ of $20: 20: 20(\mathrm{~N}: \mathrm{P}: \mathrm{K})$ fertilizer (Promisol, Lleida, Spain).

\section{Aphid colony}

Cotton aphids were collected in September, 2019 from cucumber gardens that had not been exposed to pesticides for more than 10 years. In order to condition the aphid colony to the cucumber cultivar, five generations of aphids were reared on seedlings of cv.
Super N3 in climate-controlled growth chambers set to $25 \pm 1{ }^{\circ} \mathrm{C}$, $50 \pm 5 \% \mathrm{RH}$, and a $16 \mathrm{~L}: 8 \mathrm{D}$ photoperiod.

\section{Fungal formulation}

Naturalis ${ }^{\circledR}$-L (Fargro Ltd., Arundel, United Kingdom) is an oil dispersion formulation of B. bassiana strain ATCC 74040 that contains $2.3 \times 10^{7} \mathrm{CFU} / \mathrm{ml}$. This formulation of $B$. bassiana was selected for testing because it is commercially available to growers of greenhouse cucumbers in Iran where it is frequently recommended for use in pest management programs. In addition, the active fungal ingredient of Naturalis ${ }^{\circledR}-\mathrm{L}$ was isolated for use as a positive control using the method described by Rondot \& Reineke (2018). An aliquot of $200 \mu \mathrm{l}$ of the commercial formulation was plated on a solid medium consisting of $10 \mathrm{~g}$ soy peptone, $20 \mathrm{~g}$ glucose, and $18 \mathrm{~g}$ bacterial agar dissolved in $1000 \mathrm{ml}$ sterile distilled water that had been autoclaved for $20 \mathrm{~min}$ at $121^{\circ} \mathrm{C}$. The Petri dishes were then maintained at $24^{\circ} \mathrm{C}$ in the dark for eight days, whereupon conidia were harvested by gently scraping the surface of the media and suspending the scrapings in $20 \mathrm{ml}$ Ringer's solution $(12.5 \%$, v/v) containing $0.02 \%$ Tween 80 . The concentration of conidia was then determined using a hemocytometer and adjusted to $2 \times 10^{7}$ conidia / $\mathrm{ml}$ to be the same as in the commercial formulation treatment.

\section{Virulence of $B$. bassiana topically applied to A. gossypii}

In order to assay the direct pathogenicity of B. bassiana to A. gossypii, leaf discs, each $8 \mathrm{~cm}$ diam, were cut from newlyexpanded leaves of $35 \mathrm{~d}$-old cucumber plants and each placed adaxial surface upwards on moist cotton in a plastic Petri dish $(9$ $\mathrm{cm}$ diam). Seventy five adult $A$. gossypii $(<24 \mathrm{~h}$ since final molt) were then transferred to each leaf disc $(n=4$ per treatment). Each disc was then sprayed in a Potter spray tower (Burkard Manufacturing, Rickmansworth, UK) at $69 \mathrm{kPa}$ with either Naturalis ${ }^{\circledR}-\mathrm{L}$ $(1.5 \mathrm{ml} / 1 \mathrm{~L})$, or with $2 \mathrm{ml}$ of the isolated $B$. bassiana fungus as a positive control, with $2 \mathrm{ml}$ of deionized water serving as a negative control. This resulted in deposition of $0.03 \mathrm{ml}$ of solution per $\mathrm{cm}^{2}$, or $1 \times 10^{3} \mathrm{CFU}$ of the fungus. The aphids from each replicate were then carefully transferred to a clean cucumber plant using a fine brush. Each plant ( $n=4$ per treatment) was then caged individually and the number of live aphids was tallied daily for the next seven days.

\section{Inoculation of plants with $B$. bassiana}

Once cucumber plants had two fully expanded true leaves, we covered the soil in each pot with aluminum foil (to prevent soil contamination and subsequent epiphytic colonization of untreated leaves) and then sprayed them with the recommended concentration of Naturalis ${ }^{\circledR}-\mathrm{L}(1.5 \mathrm{ml} / 1 \mathrm{~L})$, or with isolated $B$. bassiana strain as a positive control, or with sterile distilled water as a negative control. Each treatment had three replicates consisting of three plants each. Both abaxial and adaxial leaf surfaces were sprayed to run-off with a handheld sprayer (454 Handheld Sprayer, Solo ${ }^{\circledR}$ Inc., Newport News, VA, USA) operating at a pressure of two bars.

\section{Endophytic colonization of cucumber plants by B. bassiana}

Cucumber plants were evaluated for endophytic colonization by $B$. bassiana at four day intervals over a total of 48 days, and only in leaves that developed after the treatment, using the methods described by Klieber \& Reineke (2015). All treatments were replicated three times with three plants in each replicate. Three leaves were harvested from each plant (one each from the upper, middle, and lower plant parts) and individually surface-sterilized. Each leaf was first dipped in $0.5 \% \mathrm{NaOCl}$ (containing $0.05 \%$ Tween 80) for $1 \mathrm{~min}$, then in $70 \%$ ethanol for $30 \mathrm{~s}$, followed by 
two washes of $1 \mathrm{~min}$ each in sterile distilled water, and a final rinse in sterile distilled water. Water from the final rinse $(200 \mu \mathrm{l}$ in each of 3 replicates) was then plated on Beauveria selective medium (BSM) plates to verify the absence of any inoculum on the leaf surface, as per Klieber \& Reineke (2015). BSM plate medium consisted of $10 \mathrm{~g}$ soy peptone, $20 \mathrm{~g}$ glucose, and $18 \mathrm{~g}$ bacterial agar dissolved in $1000 \mathrm{ml}$ sterile distilled water and supplemented with $0.1 \mathrm{~g} / \mathrm{L}$ streptomycin, $0.05 \mathrm{~g} / \mathrm{L}$ tetracycline, $0.1 \mathrm{~g} / \mathrm{L}$ dodine, and $0.05 \mathrm{~g} / \mathrm{L}$ cyclohexamide. Surface-sterilized leaves were placed on filter paper and air-dried in a laminar flow hood, whereupon ten leaf discs (each $1 \mathrm{~cm}$ diam) were cut from each cucumber leaf using a sterilized cork borer. The leaf discs were then placed, adaxial surface upwards, on BSM plates. All plates were then incubated in the dark at $24^{\circ} \mathrm{C}$ for 20 days, at which time microscope slides of fungi growing out of the leaf discs and onto the BSM plates were prepared and examined under a binocular microscope. The presence of characteristic dense, white mycelia and clusters of conidia, matching description of Humber (1997), was considered evidence of endophytic $B$. bassiana colonization. The number of leaf discs with $B$. bassiana outgrowth was divided by the total number of leaf discs to obtain the percentage of leaf discs successfully colonized per cucumber plant.

\section{Plant growth and yield with endophytic $B$. bassiana}

In a separate experiment, cucumber plants at the 2-leaf stage (n $=3$ plants per treatment), cultivated as in "Inoculation of plants with $B$. bassiana" and similarly treated with either $1.5 \mathrm{ml} / 1 \mathrm{~L}$ of Naturalis ${ }^{\circledR}$-L, with the isolated B. bassiana fungus, or with deionized water, were harvested regularly until the end of fruit production, whereupon plant height, stem diameter, number of nodes per plant, and total yield ( $\mathrm{kg}$ fresh weight of fruit/plant) were all measured.

\section{Biochemical analysis of cucumber plants}

Biochemical analyses of cucumber plants were all conducted with three independent plant replicates using leaves that grew subsequent to treatment with Naturalis ${ }^{\circledR}-\mathrm{L}$, the isolated $B$. bassiana fungus, or with sterile water. Leaves were harvested at early flowering stages ( $28 \mathrm{~d}$ after treatment), placed in a paper bag, and dried in an oven at $35^{\circ} \mathrm{C}$ for seven days. The dry leaves of each plant were then ground with a mortar and pestle for two min, following the procedure of Espinoza et al. (2019).

Plant concentrations of phenols, alkaloids, and flavonoids were determined according to the methods of Espinoza et al. (2019), and concentrations of MDA, total chlorophyll and $\mathrm{H}_{2} \mathrm{O}_{2}$ were also assayed as indicators of plant health. To assay phenol concentrations, $25 \mu \mathrm{l}$ of aqueous ethanol extracts of dried leaves were mixed with $125 \mu \mathrm{l}$ of the Folin-Ciocalteu reagent. After five min, $100 \mu \mathrm{l}$ of $7.5 \%$ aqueous $\mathrm{Na}_{2} \mathrm{CO}_{3}$ was added. The extracts were incubated for two hours at room temperature before the absorbance was read at $765 \mathrm{~nm}$ using a spectrophotometer. The standard curve was prepared using gallic acid solutions in $10 \%$ ethanol. Concentrations of alkaloids were assayed following extraction of $100 \mathrm{mg}$ dried leaves in $10 \mathrm{ml}$ of aqueous ethanol $(60 \%)$. After centrifugation of extracts at $4000 \times \mathrm{g}$ for $10 \mathrm{~min}$, two $\mathrm{ml}$ of supernatant and atropine standard solutions were mixed with $5 \mathrm{ml}$ phosphate buffer $(50 \mathrm{mM}, \mathrm{pH} 6.8)$ and $12 \mathrm{ml}$ bromocresol green. Thereafter, $12 \mathrm{ml}$ of chloroform was added to the extracts and standards. Absorbance was measured at $417 \mathrm{~nm}$ and compared with a standard curve of atropine. Flavonoid concentrations were determined from aqueous ethanol extracts of dried leaves, using quercetin in $95 \%$ ethanol as a standard. Aqueous ethanol extracts were prepared as described above and $12.5 \mu \mathrm{l}$ of each extract was mixed with $12.5 \mu \mathrm{l}$ of $0.1 \% \mathrm{HCl}$ in $95 \%$ ethanol and $225 \mu \mathrm{l}$ of $2 \%$ $\mathrm{HCl}$ and incubated for $30 \mathrm{~min}$ at room temperature. Absorbance was read at $360 \mathrm{~nm}$ and compared with the quercetin standard curve. MDA content, which results from lipid peroxidation, was assayed with the thiobarbituric acid test, as described by Sunkar et al. (2006). Spectrophotometric measurements were performed at 532 and $600 \mathrm{~nm}$. Absorbance values at $600 \mathrm{~nm}$ were subtracted from those at $532 \mathrm{~nm}$. MDA concentrations were calculated with a molar extinction coefficient of $155 \mathrm{mM}^{-1} \mathrm{~cm}^{-1}$. Total chlorophyll content was assayed from extracts made with aqueous acetone (80\%) according to the methods of Arnon (1949), with absorbance measured spectrophotometrically at $663 \mathrm{~nm}$ (for chlorophyll A) and $645 \mathrm{~nm}$ (for chlorophyll B). $\mathrm{H}_{2} \mathrm{O}_{2}$ content was estimated according to the method of Velikova et al. (2000), which is based on potassium iodide oxidation by $\mathrm{H}_{2} \mathrm{O}_{2}$ in an acidic medium, followed by a measurement of absorbance of the reaction mixture at $390 \mathrm{~nm}$.

\section{Biochemical analysis of $A$. gossypii}

Treated plants in early flowering stages ( $28 \mathrm{~d}$ post-inoculation with either Naturalis ${ }^{\mathbb{B}}-\mathrm{L}$ or the isolated $B$. bassiana fungus, $\mathrm{n}=$ 3 plants per treatment) and control plants (inoculated with sterile water) were each manually infested with about 450 apterous adults of $A$. gossypii, the action threshold for this aphid on 35 d-old plants, and caged individually. Plants were treated as described above in "Inoculation of plants with B. bassiana". Cotton aphids were allowed access only to leaves that had fully expanded subsequent to treatment; the first two (treated) leaves were tightly covered in muslin fabric to prevent aphid access. After feeding on plants for $24 \mathrm{~h}$, the aphids were collected, frozen in liquid nitrogen, and stored at $-80^{\circ} \mathrm{C}$.

Three independent biological replicates of A. gossypii were analyzed for each metabolite. Activities of detoxifying enzymes, including glutathione-S-transferase (GST), carboxylesterase (COE), and acetylcholinesterase (AChE), were assayed based on the methods of Kandil et al. (2017). For the GST assay, replicates consisted of 10 apterous adult $A$. gossypii from each treatment homogenized in $200 \mu \mathrm{l}$ phosphate buffer $(0.1 \mathrm{M}, \mathrm{pH} 6.5)$ and then centrifuged at $12000 \times g$ for $15 \mathrm{~min}$ at $4{ }^{\circ} \mathrm{C}$ to obtain supernatants. $100 \mu 1$ samples of the supernatant were treated with $10 \mu 11$-chloro-2,4-dinitrobenzene $(30 \mathrm{mM})$, and $10 \mu \mathrm{GSH}(50 \mathrm{mM})$. Enzyme activity was determined by continuous monitoring of changes in absorbance at $430 \mathrm{~nm}$ for three min at $25^{\circ} \mathrm{C}$. COE activity was determined using $\alpha$-naphthyl acetate $(\alpha$-NA) as a substrate. For each replicate, 50 apterous $A$. gossypii adults were homogenized in $500 \mu 1$ of phosphate buffer $(0.1 \mathrm{M}, \mathrm{pH} 7.0)$ and centrifuged at $12000 \times g$ for $15 \mathrm{~min}$ at $4^{\circ} \mathrm{C}$ to obtain the supernatant. Then, $50 \mu 1$ samples of the supernatant were incubated with $50 \mu 1 \alpha$-NA (30 $\mathrm{mM}$ ) for $15 \mathrm{~min}$ at $30^{\circ} \mathrm{C}$. The reaction was stopped by adding 50 $\mu 1$ of Fast Blue RR. Absorbance was measured at $600 \mathrm{~nm}$ to assay the hydrolysis of $\alpha$-NA and the $\alpha$-naphthol standard curves were then used to calculate enzyme activity. AChE activity was determined for each replicate by homogenizing 25 apterous $A$. gossypii adults in $200 \mu \mathrm{l}$ of $0.1 \mathrm{M}$ phosphate buffer $(\mathrm{pH} 7.5)$ containing Triton X-100. After centrifugation of homogenized samples at $3000 \times g$ for $15 \mathrm{~min}$ at $4^{\circ} \mathrm{C}, 25 \mu 1$ samples of the supernatant were treated with $2 \mu \mathrm{l}$ of $0.075 \mathrm{M}$ acetylcholine iodide, $8 \mu \mathrm{l}$ of $0.01 \mathrm{M} 5,5^{\prime}$-dithiobis-2-nitrobenzoic acid and phosphate buffer $(0.1 \mathrm{M}, \mathrm{pH} 7.5)$. Change in absorbance was measured at $405 \mathrm{~nm}$ over $20 \mathrm{~min}$.

The energy reserves of $A$. gossypii, including protein, carbohydrate, lipid, and glycogen, were assayed according to the methods described by Foray et al. (2012). A Bradford assay was used to evaluate protein content, with absorbance read at $595 \mathrm{~nm}$. Sample absorbance was compared with a bovine serum albumin standard curve. Glycogen was dissolved by addition of $20 \mu 1$ of sodium sulfate solution (20\%) and lipid and carbohydrate were solubi- 
lized by mixing the solution with $1500 \mu \mathrm{l}$ of a chloroform-methanol solution $(1: 2 \mathrm{v} / \mathrm{v})$. Glycogen and carbohydrate contents were determined colorimetrically using the anthrone reagent at $630 \mathrm{~nm}$ with glucose as the standard. Lipid content was determined at 525 $\mathrm{nm}$ following addition of vanillin as a reagent and using cholesterol as the standard.

In addition, the activities of digestive enzymes including lipase, $\alpha$-amylase, $\alpha$-glucosidase, and aminopeptidase were analyzed according to the methods of Mardani-Talaee et al. (2016). For each replicate, 20 apterous $A$. gossypii adults were homogenized in $\mathrm{NaCl}$ solution $(0.15 \mathrm{M})$ and centrifuged at $20000 \times \mathrm{g}$ for $5 \mathrm{~min}$ at $4^{\circ} \mathrm{C}$. The activity of lipase was estimated using a $10 \mu 1$ enzyme sample and $20 \mu \mathrm{l}$ of p-nitrophenyl butyrate $(27 \mathrm{mM})$ as substrate, both added to $50 \mu \mathrm{l}$ of universal buffer ( $\mathrm{pH} 7)$, mixed thoroughly, and incubated at $37^{\circ} \mathrm{C}$. After one minute, $100 \mu \mathrm{l}$ of sodium hydroxide $(1 \mathrm{M})$ was added and absorbance was read at $405 \mathrm{~nm}$. Activity of $\alpha$-amylase was determined using starch (1\%) and dinitrosalicylic acid (DNS). $20 \mu \mathrm{l}$ of enzyme sample was incubated with $40 \mu \mathrm{l}$ of starch solution (1\%) and $80 \mu \mathrm{l}$ of universal buffer (pH 7) for $30 \mathrm{~min}$ at $35^{\circ} \mathrm{C}$. Then, $100 \mu \mathrm{l}$ of DNS was added, and the tubes containing the reaction mixture were incubated for another $10 \mathrm{~min}$ in a boiling water bath. Finally, the absorbance of $100 \mu \mathrm{l}$ of the reaction mixture was read at $540 \mathrm{~nm}$. The activity of $\alpha$-glucosidase was assayed by adding $20 \mu 1$ of $p$-nitrophenol- $\alpha$ glucopyranoside $(5 \mathrm{mM})$ in $50 \mu \mathrm{l}$ of universal buffer $(\mathrm{pH} 7)$. Enzyme samples $(10 \mu \mathrm{l})$ were incubated for $10 \mathrm{~min}$ prior to reading absorbance at $405 \mathrm{~nm}$. The activity of aminopeptidase was determined using hippuryl-L-phenylalanine as a substrate $(1 \mathrm{mM}) .20$ $\mu l$ of the substrate was added to $50 \mu 1$ of universal buffer $(20 \mathrm{mM}$, $\mathrm{pH} 7)$ and enzyme samples $(10 \mu \mathrm{l})$ were incubated for $10 \mathrm{~min}$ at $30^{\circ} \mathrm{C}$. The reaction was terminated by adding $100 \mu \mathrm{l}$ of TCA $(30 \%)$ and absorbance was read at $340 \mathrm{~nm}$.

Measurements of antioxidant enzyme activities, including superoxide dismutase (SOD), catalase (CAT), and ascorbate peroxidase (APX), were conducted according to the method of Mardani-Talaee et al. (2016). For each replicate, 20 apterous $A$. gossypii adults were homogenized in $\mathrm{NaCl}$ solution $(0.15 \mathrm{M})$ and centrifuged at $20000 \times g$ for $5 \mathrm{~min}$ at $4^{\circ} \mathrm{C}$. SOD activity was determined based on its inhibition of the reaction of nitro blue tetrazolium (NBT) with superoxide anion due to xanthine oxidation. Enzyme samples $(100 \mu \mathrm{l})$ were added to $500 \mu \mathrm{l}$ of reaction mixtures containing $70 \mu \mathrm{M}$ of NBT and $125 \mu \mathrm{M}$ of xanthine, both dissolved in phosphate buffered saline and the xanthine oxidase solution. The reaction mixture was incubated in darkness for 20 min at $25^{\circ} \mathrm{C}$ before activity was read at $560 \mathrm{~nm}$. For CAT activity, $100 \mu \mathrm{l}$ of enzyme sample was added into $500 \mu$ l of hydrogen peroxide $(1 \%)$, incubated at $25^{\circ} \mathrm{C}$ for $10 \mathrm{~min}$, and the activity was determined by reading the absorbance at $240 \mathrm{~nm}$. For APX activity, reaction mixtures consisted of $100 \mu \mathrm{l}$ of enzyme sample and $250 \mu \mathrm{l}$ of $67 \mathrm{mM}$ phosphate buffer $(\mathrm{pH} \mathrm{7)}$ containing 2.5 $\mathrm{mM}$ ascorbic acid, and $200 \mu \mathrm{l}$ of $30 \mathrm{mM}$ hydrogen peroxide. The change in absorbance at $290 \mathrm{~nm}$ was recorded over five min. Activity of phenoloxidase (PO) was quantified using the procedure described by Wu et al. (2015). For each replicate, 20 apterous $A$. gossypii adults were homogenized in $10 \mathrm{mM}$ Tris-buffer $(\mathrm{pH} 7.4)$ and centrifuged at $10000 \times g$ for $5 \mathrm{~min}$ at $4^{\circ} \mathrm{C}$. Then, $25 \mu \mathrm{l}$ aliquots of enzyme sample were added into $75 \mu \mathrm{l}$ of 3,4-dihydroxyL-phenylalanine and $100 \mu \mathrm{l}$ phosphate buffer (pH 5.8), incubated at $30^{\circ} \mathrm{C}$ for $5 \mathrm{~min}$. Activity was assayed by reading the absorbance at $490 \mathrm{~nm}$.

\section{Life history of $\boldsymbol{A}$. gossypii}

To determine the effects of endophytic $B$. bassiana on the life history and reproductive success of $A$. gossypii, cucumbers were treated at the two-leaf stage with either Naturalis ${ }^{\mathbb{}}-\mathrm{L}$, the isolated $B$. bassiana fungus, or sterile water, and then allowed to grow for 28 days, as described above for assays of plant metabolites. The treated leaves (first two true leaves) were encased in muslin fabric to prevent aphid access. Then, approximately 450 apterous adult aphids were placed on each cucumber plant ( $\mathrm{n}=3$ per treatment) and plants were caged individually.

After $24 \mathrm{~h}$ of feeding, all surviving aphids were transferred individually to fresh, untreated cucumber leaf discs $(3.5 \mathrm{~cm}$ diam $)$, one apterous female per disc, to determine their fecundity, longevity and reproductive period. This procedure standardized the feeding period and assayed the acute effects of short-term feeding exposure. Leaf discs were each isolated on $2 \%$ agar $(2 \mathrm{~cm}$ deep) in a glass Petri dishes $(8 \mathrm{~cm}$ diam) and replaced every 3 days. Only the adult female was transferred to the new leaf disc; its survival and the numbers of nymphs she produced were recorded daily until she died.

\section{Susceptibility of $\boldsymbol{A}$. gossypii to pirimicarb}

Toxicity bioassays with pirimicarb were conducted on apterous $A$. gossypii adults that had fed on either Naturalis ${ }^{\circledR}$ L-treated, $B$. bassiana isolate-treated, or untreated cucumber plants. Plants were treated at the two-leaf stage and maintained as described above; treated leaves were encased in muslin to prevent access to aphids. Twenty eight days after treatment, approximately 450 apterous adult $A$. gossypii were transferred onto leaves of treated and control cucumber plants ( $\mathrm{n}=3$ in all cases). The aphids fed for $24 \mathrm{~h}$ before use in bioassays.

Based on bracketing tests, five concentrations of pirimicarb (Pirimor ${ }^{\circledR} 50 \mathrm{WG}$, Syngenta, Switzerland), specifically $0.05,0.1$, $0.2,0.4$, and $0.8 \mathrm{mg}$ a.i./L, and an untreated control (sterile distilled water) were used to estimate $\mathrm{LC}_{50}$ values. Previous work indicated that these concentrations should cause mortality ranging from $10 \%-90 \%$ (Robertson et al., 2017). According to the method of Moores et al. (1996), cucumber leaf discs (each $1 \mathrm{~cm}$ diam, not exposed to B. bassiana) were cut from each leaf using a sterilized cork borer, dipped in the appropriate pirimicarb solution for $5 \mathrm{~s}$, air-dried, and then placed with the adaxial surface down on a $2 \%$ agar bed in Petri dishes (as described under "Life history of $A$. gossypii"), one per dish. Each replicate $(\mathrm{n}=3)$ consisted of twenty apterous $A$. gossypii adults placed on a single leaf disc. Petri dishes were held at $25 \pm 1{ }^{\circ} \mathrm{C}, 50 \pm 5 \% \mathrm{RH}$, and a $16 \mathrm{~L}: 8 \mathrm{D}$ photoperiod in a growth chamber. Mortality was recorded $24 \mathrm{~h}$ later and probit analysis was conducted to estimate $\mathrm{LC}_{50}$ values.

\section{Statistical analysis}

Mortality data for $A$. gossypii following direct application of $B$. bassiana were analyzed by Chi-square, Goodness-of-fit test and Kaplan-Meier plots were generated. Data from the biochemical analysis of plants and aphids, as well as the aphid life history data, plant morphological data, and yield data were subjected to one-way ANOVA followed by Bonferroni test to separate means, after they passed tests for normality (Shapiro-Wilkes) and equality of variances (Levine's test). All analyses were performed in GraphPad Prism version 8.2.0 (GraphPad, 2019).

$\mathrm{LC}_{50}$ values, slopes, and $95 \%$ confidence intervals $(95 \% \mathrm{CI})$ for the pirimicarb toxicity assays were estimated using Polo Plus version 2.0 (Polo, 2007). Significant differences between $\mathrm{LC}_{50}$ values were determined by logit regression to compare slopes and intercepts of logit lines, as described by Robertson et al. (2017). 


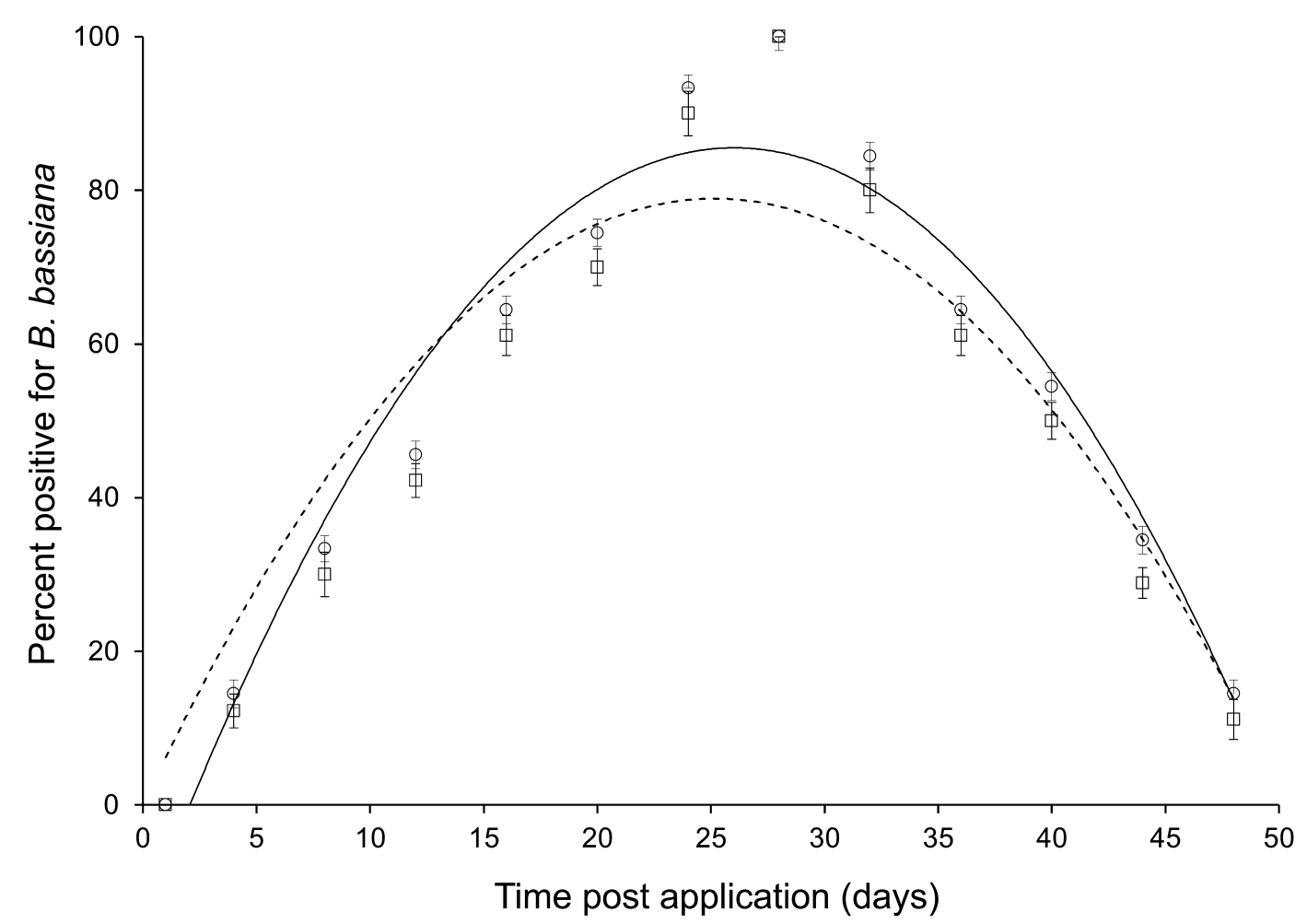

Fig. 1. Mean $( \pm S E)$ percentage of cucumber leaf discs ( $n=10$ per day) positive for endophytic Beauveria bassiana when harvested vari-

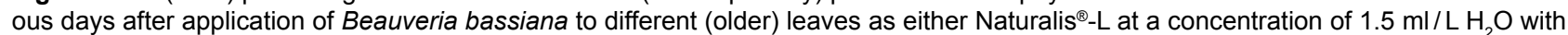
$0.03 \mathrm{ml}$ of solution deposited per $\mathrm{cm}^{2}$, or $1 \times 10^{3} \mathrm{CFU}$ per $\mathrm{cm}^{2}$ (circles, solid line) or as the $B$. bassiana isolate alone at a concentration of $2 \times 10^{7} \mathrm{CFU} / \mathrm{ml}$ (squares, hatched line).

\section{RESULTS}

\section{Endophytic colonization of cucumber plants by $B$. bassiana}

Beauveria bassiana successfully colonized cucumber leaves that developed subsequent to the application of Naturalis ${ }^{\circledR}-\mathrm{L}(1.5 \mathrm{ml} / \mathrm{L})$, or the isolated B. bassiana fungus, on the first true leaves. The fungus colonized the plants progressively until all leaf discs taken from all plants inoculated with B. bassiana (100\%) showed endophytic establishment 28 days after treatment, with the proportion positive for the fungus declining thereafter (Fig. 1), whereas leaf discs from control plants did not show any signs of fungal outgrowth (data not shown). Similarly, no fungal growth was observed on the plates receiving the final rinse water, confirming no inoculum was present on the surfaces of the leaves.

\section{Virulence of $B$. bassiana topically applied to A. gossypii}

Aphids treated with either Naturalis ${ }^{\circledR}-\mathrm{L}$ or the $B$. bassiana isolate alone died at similar rates and were all dead

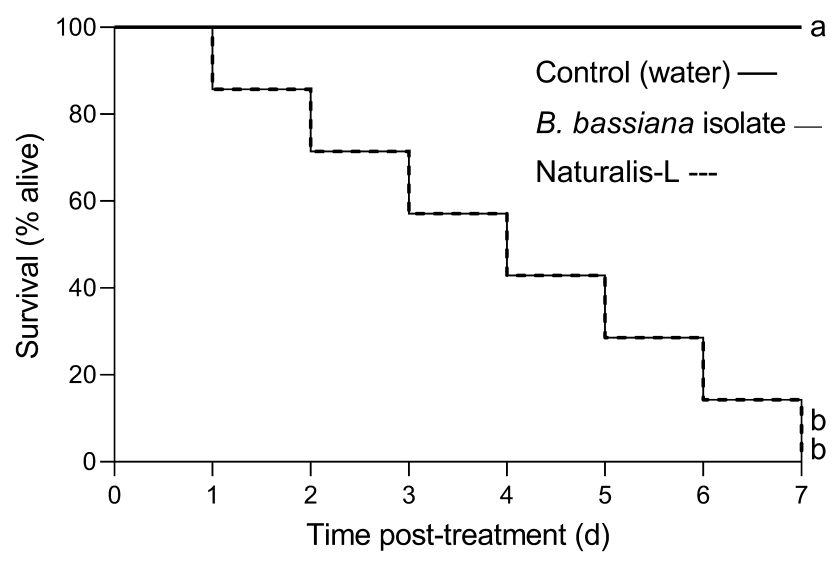

Fig. 2. Kaplan Meier plot of mortality of adult Aphis gossypii topically treated with either Naturalis ${ }^{\circledR} \mathrm{L}$ (at a concentration of $1.5 \mathrm{ml} / \mathrm{L}$ $\mathrm{H}_{2} \mathrm{O}$ with $0.03 \mathrm{ml}$ of solution deposited per $\mathrm{cm}^{2}$, or $1 \times 10^{3} \mathrm{CFU}$ per $\mathrm{cm}^{2}$ ), or with the Beauveria bassiana isolate alone (at a concentration of $2 \times 10^{7} \mathrm{CFU} / \mathrm{ml}$ ). Curves bearing different letters were significantly different at end of experiment (Control vs Naturalis ${ }^{\circledR}-\mathrm{L}$ : $X^{2}=60.45, P<0.001$; Control vs $B$. bassiana: $X^{2}=59.11, P<0.001$; Naturalis ${ }^{\oplus}$ L vs $B$. bassiana: $\left.X^{2}=0.002, P=0.981\right)$.

Table 1. Mean $( \pm S E)$ plant growth and yield parameters for cucumber plants $\left(n=3\right.$ per treatment) when treated with Naturalis ${ }^{\circledR}-L_{\text {, the }} B$. bassiana isolate alone, or water (Control) at the 2-leaf stage and then evaluated post-harvest. Values bearing different letters were significantly different within rows (ANOVA followed by Bonferroni, $\alpha=0.05$ ).

\begin{tabular}{|c|c|c|c|c|c|}
\hline Variable (units) & Control & Naturalis $^{\circledR}-\mathrm{L}$ & B. bassiana & $F_{2,6}$ & $P$ \\
\hline Plant height $(\mathrm{cm})$ & $220.0 \pm 8.4^{a}$ & $235.0 \pm 11.3^{a}$ & $228.0 \pm 9.2^{\mathrm{a}}$ & 29.54 & 0.09 \\
\hline Stem diameter (cm) & $1.5 \pm 0.12^{\mathrm{a}}$ & $1.6 \pm 0.15^{\mathrm{a}}$ & $1.5 \pm 0.11^{\mathrm{a}}$ & 26.56 & 0.08 \\
\hline Nodes per plant (no.) & $30.9 \pm 2.01^{a}$ & $34.8 \pm 2.14^{a}$ & $32.7 \pm 2.23^{a}$ & 23.85 & 0.06 \\
\hline Yield (fresh weight in kg) & $5.1 \pm 0.24^{a}$ & $5.6 \pm 0.28^{a}$ & $5.4 \pm 0.26^{a}$ & 24.71 & 0.07 \\
\hline
\end{tabular}



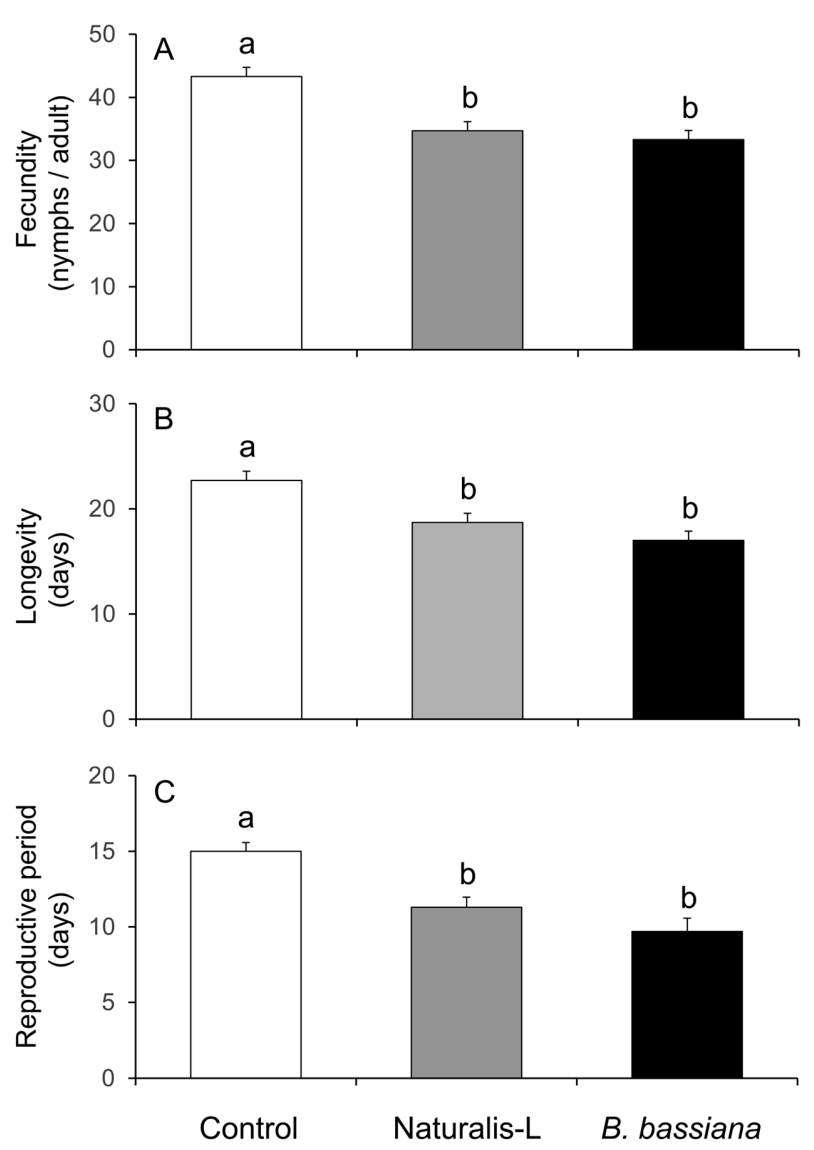

Fig. 3. Mean $( \pm S E)$ fecundities, longevities, and reproductive periods of Aphis gossypii apterous females that fed on cucumber plants that were inoculated with either Naturalis ${ }^{\circledR}$-L (at a concentration of $1.5 \mathrm{ml} / \mathrm{L} \mathrm{H}_{2} \mathrm{O}$, with $0.03 \mathrm{ml}$ of solution deposited per $\mathrm{cm}^{2}$, or $1 \times 10^{3} \mathrm{CFU}$ per $\mathrm{cm}^{2}$ ), the Beauveria bassiana isolate alone (at a concentration of $2 \times 10^{7} \mathrm{CFU} / \mathrm{ml}$ ), or water (Control) for $24 \mathrm{~h}$ before transfer to an untreated leaf disc. Values bearing different letters were significant different (ANOVA followed by Bonferroni, $\alpha=0.05$ ).

after seven days, whereas control aphids experienced no mortality within this time frame (Fig. 2).

\section{Plant growth and yield with endophytic $B$. bassiana}

At end of harvest, plants receiving treatment with either Naturalis $^{\mathbb{B}} \mathrm{-L}$ or the $B$. bassiana isolate did not differ significantly from control plants in any component of yield (Table 1).

\section{Biochemical analysis of cucumber plants}

Cucumber plants inoculated with either Naturalis ${ }^{\circledR}-\mathrm{L}$ or the $B$. bassiana isolate had significantly higher levels of alkaloids, flavonoids, phenols, $\mathrm{H}_{2} \mathrm{O}_{2}$, and total chlorophyll when compared to control plants, whereas concentrations of MDA did not differ between treatment and control plants (Table 2).

\section{Biochemical analysis of $A$. gossypii}

Aphids that fed on plants inoculated with either Naturalis ${ }^{\circledR}$-L or the $B$. bassiana isolate had significantly lower activity of COE, GST, and AChE when compared with aphids that fed on plants treated only with water (Table $3)$. Similarly, activities of lipase, $\alpha$-amylase, $\alpha$-glucosidase, aminopeptidase, and CAT were significantly lower in aphids that fed on fungus-treated plants compared to controls, whereas activities of SOD, APX, and PO were all higher.

Cotton aphids from fungus-treated plants had greater carbohydrate content compared to those that fed on controls, whereas protein content, glycogen content, and lipid content were all lower compared to controls (Table 3).

\section{Biological traits of $\boldsymbol{A}$. gossypii}

Cotton aphids that fed on fungi-inoculated plants had significantly lower fecundity $\left(F_{2,6}=18.56, P=0.041\right)$, reduced longevity $\left(F_{2.6}=16.35, P=0.020\right)$, and shorter reproductive periods $\left(F_{2,6}=14.44, P=0.015\right)$ compared to aphids that fed on control plants (Fig. 3).

\section{Susceptibility of $\boldsymbol{A}$. gossypii to pirimicarb}

The $\mathrm{LC}_{50}$ values of pirimicarb for $A$. gossypii that fed on fungus-inoculated plants were reduced to approximately half that of control aphids (Table 4), but did not differ significantly whether Naturalis ${ }^{\circledR}-\mathrm{L}$ or the $B$. bassiana isolate was used, indicating that endophytic colonization of cucumber plants with $B$. bassiana increased the susceptibility of $A$. gossypii to pirimicarb.

\section{DISCUSSION}

Treatment of cucumber seedlings with $B$. bassiana at the 2-leaf stage, whether using the Naturalis ${ }^{\circledR}$-L formulation or the fungal isolate alone, resulted in endophytic fungal growth and colonization of plant tissues that expanded and developed, peaking around 28 days post-application, and declining thereafter. Endophytic fungi may eventually decline within inoculated plants in response to various factors, such as the immune responses of plant tissues, or competition with other endophytes present in the plant (Posada et al., 2007; Gurulingappa et al., 2010). Endophytic colonization of cucumber by $B$. bassiana resulted in increased

Table 2. Mean $( \pm \mathrm{SE})$ concentrations $(\mathrm{mg} / \mathrm{g} \mathrm{DW})$ of various metabolites in cucumber plants $(\mathrm{n}=3$ per treatment) when treated with either Naturalis $^{\circledR}$-L, the $B$. bassiana isolate alone, or water (Control), at the 2-leaf stage and then assayed in early flowering stages (28 $\mathrm{d}$ posttreatment). Abbreviations: Hydrogen peroxide $\left(\mathrm{H}_{2} \mathrm{O}_{2}\right)$, malondialdehyde (MDA). Values bearing different letters were significantly different within rows (ANOVA followed by Bonferroni, $\alpha=0.05$ ).

\begin{tabular}{|c|c|c|c|c|c|}
\hline Variable (units) & Control & Naturalis $^{\circledR}-\mathrm{L}$ & B. bassiana & $F_{2,6}$ & $P$ \\
\hline Alkaloids & $1.85 \pm 0.04^{b}$ & $2.18 \pm 0.03^{a}$ & $2.09 \pm 0.05^{a}$ & 12.63 & 0.01 \\
\hline Flavonoids & $2.61 \pm 0.12^{b}$ & $3.12 \pm 0.11^{\mathrm{a}}$ & $2.98 \pm 0.10^{a}$ & 13.45 & 0.04 \\
\hline Phenols & $1.11 \pm 0.05^{b}$ & $1.48 \pm 0.04^{a}$ & $1.37 \pm 0.06^{a}$ & 14.96 & 0.02 \\
\hline Hydrogen peroxide $\left(\mathrm{H}_{2} \mathrm{O}_{2}\right)$ & $0.40 \pm 0.01^{b}$ & $0.49 \pm 0.02^{a}$ & $0.47 \pm 0.03^{a}$ & 11.63 & 0.03 \\
\hline Total chlorophyll & $1.32 \pm 0.04^{b}$ & $1.57 \pm 0.05^{a}$ & $1.50 \pm 0.04^{a}$ & 16.89 & 0.01 \\
\hline Maldonaldehyde (MDA) & $1.81 \pm 0.08^{a}$ & $1.85 \pm 0.07^{a}$ & $1.83 \pm 0.06^{a}$ & 21.99 & 0.09 \\
\hline
\end{tabular}


Table 3. Mean ( \pm SE) specific activities of various enzymes in Aphis gossypii tissues and mean concentrations of other non-enzymatic compounds, when plants ( $\mathrm{n}=3$ per treatment) were treated with Naturalis $®$ - $\mathrm{L}$, the $B$. bassiana isolate alone, or water (Control) at the 2-leaf stage and assayed in early flowering stages (28 d post-treatment). Plants were infested with ca. 450 adult $A$. gossypii apterae per plant and, $24 \mathrm{~h}$ after treatment, aphid samples were analyzed in three replicates. Abbreviations: carboxylesterase (COE), glutathione-Stransferase (GST), acetylcholinesterase (AChE), superoxide dismutase (SOD), ascorbate peroxidase (APX), phenoloxidase (PO), catalase (CAT). Values bearing different letters were significantly different within rows (ANOVA followed by Bonferroni, $\alpha=0.05$ ).

\begin{tabular}{|c|c|c|c|c|c|}
\hline Variable & Naturalis@-L & B. bassiana & Control & $F_{2,6}$ & $\mathrm{P}$ \\
\hline COE ( $\mu \mathrm{mol} / \mathrm{min} / \mathrm{mg}$ protein) & $0.13 \pm 0.01 b$ & $0.14 \pm 0.01 b$ & $0.19 \pm 0.01 a$ & 18.11 & 0.01 \\
\hline GST (nmol / min / mg protein) & $45.22 \pm 0.86 b$ & $47.13 \pm 0.75 b$ & $52.75 \pm 0.91 a$ & 16.28 & 0.04 \\
\hline $\mathrm{AChE}$ (nmol/min / mg protein) & $2.15 \pm 0.02 b$ & $2.18 \pm 0.03 b$ & $2.59 \pm 0.04 a$ & 15.48 & 0.02 \\
\hline Lipase ( $\mu \mathrm{mol} / \mathrm{min} / \mathrm{mg}$ protein) & $54.53 \pm 0.81 b$ & $56.13 \pm 0.72 b$ & $59.93 \pm 0.99 a$ & 13.71 & 0.03 \\
\hline$\alpha$-amylase ( $\mu \mathrm{mol} / \mathrm{min} / \mathrm{mg}$ protein $)$ & $4.46 \pm 0.11 b$ & $4.60 \pm 0.08 b$ & $4.98 \pm 0.09 a$ & 12.36 & 0.01 \\
\hline$\alpha$-glucosidase ( $\mu \mathrm{mol} / \mathrm{min} / \mathrm{mg}$ protein) & $53.00 \pm 0.82 b$ & $55.13 \pm 0.70 b$ & $58.98 \pm 0.92 a$ & 10.89 & 0.02 \\
\hline Aminopeptidase ( $\mu \mathrm{mol} / \mathrm{min} / \mathrm{mg}$ protein) & $0.07 \pm 0.01 b$ & $0.08 \pm 0.01 b$ & $0.11 \pm 0.01 a$ & 17.85 & 0.04 \\
\hline SOD ( $\mu \mathrm{mol} / \mathrm{min} / \mathrm{mg}$ protein) & $0.16 \pm 0.01 a$ & $0.14 \pm 0.01 a$ & $0.10 \pm 0.01 b$ & 14.90 & 0.03 \\
\hline $\mathrm{APX}(\mu \mathrm{mol} / \mathrm{min} / \mathrm{mg}$ protein $)$ & $1.16 \pm 0.02 a$ & $1.14 \pm 0.02 a$ & $1.01 \pm 0.01 b$ & 11.23 & 0.01 \\
\hline $\mathrm{PO}$ (nmol / $\mathrm{min} / \mathrm{mg}$ protein) & $47.14 \pm 0.71 a$ & $45.13 \pm 0.91 a$ & $40.82 \pm 0.89 b$ & 18.95 & 0.02 \\
\hline CAT $(\mu \mathrm{mol} / \mathrm{min} / \mathrm{mg}$ protein $)$ & $0.31 \pm 0.02 b$ & $0.33 \pm 0.01 b$ & $0.38 \pm 0.02 a$ & 15.36 & 0.02 \\
\hline Carbohydrate ( $\mu \mathrm{g} /$ insect) & $13.91 \pm 0.33 a$ & $13.56 \pm 0.21 a$ & $12.21 \pm 0.18 b$ & 16.80 & 0.01 \\
\hline Protein ( $\mu \mathrm{g} /$ insect) & $34.13 \pm 0.46 b$ & $36.00 \pm 0.31 b$ & $38.51 \pm 0.52 a$ & 12.12 & 0.03 \\
\hline Glycogen ( $\mu \mathrm{g} /$ insect) & $7.13 \pm 0.17 b$ & $8.02 \pm 0.19 b$ & $9.92 \pm 0.14 a$ & 13.85 & 0.04 \\
\hline Lipid ( $\mu \mathrm{g} /$ insect) & $5.11 \pm 0.13 b$ & $5.33 \pm 0.19 b$ & $5.89 \pm 0.11 a$ & 10.11 & 0.04 \\
\hline
\end{tabular}

levels of several metabolites within plants that have roles in plant defense against herbivores, but had no measurable effect on plant fitness, morphological parameters, or final yield. Elevated levels of these metabolites may have resulted either from endophyte-induced production by the plant (Vega, 2018), or from their production by the endophyte itself (Jaber \& Ownley, 2018). Ultimately, A. gossypii that fed on fungus-inoculated plants showed reduced activities of detoxifying, digestive, and antioxidant enzymes, as well as reduced storage of energic compounds, all indications of physiological stress. These physiological impacts translated into reduced longevity, fecundity, and reproductive periods and rendered $A$. gossypii more susceptible to pirimicarb, a commonly used aphicide in Iranian greenhouses.

Topical application of B. bassiana to adult A. gossypii, whether as the Naturalis ${ }^{\circledR}$ - $\mathrm{L}$ formulation or the fungal isolate alone, resulted in significant mortality relative to controls at $24 \mathrm{~h}$ after treatment, and complete mortality after seven days, a significantly higher mortality than observed in control aphids. It has been previously demonstrated that applications of $B$. bassiana cause significant direct mortality to A. gossypii (e.g., Kang et al., 2008; Degefu et al., 2014), and any progeny produced by these aphids prior to death will be subject to the adverse impacts of endophytic B. bassiana.

MDA is a lipid peroxidation biomarker and a metabolite indicative of plant stress (Heidarvand \& Maali-Amiri, 2013), but we found no significant difference in MDA levels between fungus-treated and untreated plants, suggesting that endophytic colonization of cucumber by $B$. bassiana did not stress the plant. On the contrary, we found evidence of physiological benefits of endophytic B. bassiana in treated plants in the form of higher levels of total chlorophyll. Similarly, Sanchez-Rodriguez et al. (2015) demonstrated benefits of $B$. bassiana endophytic colonization of tomato and wheat in the form of improved iron nutrition on calcareous soils associated with iron chlorosis.

Levels of alkaloids, flavonoids, phenols, and hydrogen peroxide increased in fungus-treated plants, relative to controls, by the time they reached early flowering stages. Similarly, Espinoza et al. (2019) found significant increases in the alkaloid content of chive plants, Allium schoenoprasum, three weeks post-inoculation with $B$. bassiana. Endophytic enhancement of such compounds has been linked to adverse impacts on various herbivorous insects (Rondot \& Reineke, 2018; Vega, 2018). These secondary metabolites may be endogenously produced by endophytic fungi, sometimes using genes acquired from their host plants, or via epigenetic modification of gene expression within the plant (Meena et al., 2019). However, plant responses to endophytic $B$. bassiana can vary greatly among species and modes of inoculation (Sanchez-Rodriguez et al., 2018). For example, Moloinyane \& Nchu (2019) found that $B$. bassiana inoculation of grape vines, although only $50 \%$ successful, caused elevated concentrations of calcium and magnesium in plant tissues, and enhanced the production of various anti-insect volatile compounds, without altering levels of polyphenols, flavonoids or alkaloids.

Because endophytic $B$. bassiana can alter plant physiology and biochemical composition in complex ways, its ef-

Table 4. Toxicity of pirimicarb to A. gossypii ( $n=360$ aphids per treatment) that were fed on leaves of cucumber plants inoculated either with Naturalis ${ }^{\circledR}-\mathrm{L}$, the $B$. bassiana isolate alone, or water (Control). $\mathrm{LC}_{50}$ values bearing different letters had significantly different logit lines in logit regression.

\begin{tabular}{lccccc}
\hline & $\mathrm{LC}_{50}\left(\mathrm{mg} \mathrm{L}^{-1}\right)$ & $95 \% \mathrm{Cl}$ & Slope $\pm \mathrm{SE}$ & $\mathrm{X}^{2}(\mathrm{df})$ & Heterogeneity \\
\hline Control & $0.08^{\mathrm{a}}$ & $0.06-0.11$ & $1.96 \pm 0.47$ & $0.28(13)$ & $4.55(13)$ \\
Naturalis ${ }^{\circledR}-\mathrm{L}$ & $0.04^{\mathrm{b}}$ & $0.02-0.07$ & $1.31 \pm 0.22$ & 0.45 \\
B. bassiana & $0.05^{\mathrm{b}}$ & $0.03-0.08$ & $1.39 \pm 0.28$ & $5.80(13)$ & 0.66 \\
\hline
\end{tabular}


fects on insect herbivores can be equally diverse and complex (McKinnon et al., 2017). We found that the activity of at least three important detoxification enzymes, GST, COE, and $\mathrm{AChE}$, were substantially reduced in cotton aphids that fed on B. bassiana-inoculated plants. These particular enzymes provide key mechanisms for the detoxification of plant defensive chemicals and other xenobiotics (Despres et al., 2007), while also maintaining normal physiological functions (Singh et al., 2019). GST activity is known to be inhibited by phenols (Lukasik \& Golawska, 2007) and flavonoids (Yu \& Abo-Elghar, 2000). Similarly, the activity of AChE can be inhibited by phenols and alkaloids (Wink et al., 1998; Rajashekar et al., 2014), and the activity of COE can be inhibited by phenols (Juntheikki \& JulkunenTiitto, 2000) and flavonoids (Wang et al., 2016). Therefore, it is likely that the elevated levels of alkaloids, flavonoids, and phenols in B. bassiana-inoculated plants were at least partially responsible for the reduced activity of detoxifying enzymes in $A$. gossypii that fed on these plants.

Feeding on plants inoculated either with Naturalis ${ }^{\circledR}-\mathrm{L}$ or the $B$. bassiana isolate also reduced the activities of digestive enzymes in A. gossypii. These plants had higher levels of $\mathrm{H}_{2} \mathrm{O}_{2}$ relative to control plants, which can disrupt enzyme functions in insects (Felton \& Duffey, 1991), have toxicological effects on herbivore midguts (Bi \& Felton, 1995), and damage the insect digestive system (War et al., 2012). Phenols can also inhibit digestive enzymes (Johnson \& Felton, 2001), and the production of semiquinone in the herbivore lumen, resulting in cytotoxic effects on lumen tissues (Barbehenn et al., 2010). Thus, the decreased activities of $A$. gossypii digestive enzymes on fungus-isolated cucumber plants probably result from increases in the phenolic and $\mathrm{H}_{2} \mathrm{O}_{2}$ contents of plants induced by $\mathrm{B}$. bassi$a n a$, and likely contributed to the lower reproductive success and fitness of aphids on these plants.

Aphids that fed on B. bassiana-inoculated plants had higher levels of antioxidant enzymes than those that fed on control plants. Antioxidants such as SOD can be induced by flavonoids (Ahmad \& Pardini, 1990) and phenols (Lukasik, 2007), so the increased activity of SOD in A. gossypii on fungus-inoculated plants may be linked to the increased levels of flavonoids and phenols in these plants. SOD catalyzes the dismutation of the superoxide anion into $\mathrm{H}_{2} \mathrm{O}_{2}$. Consequently, increased SOD activity in cotton aphids may result in $\mathrm{H}_{2} \mathrm{O}_{2}$ production, a toxic free radical that is subsequently metabolized to $\mathrm{H}_{2} \mathrm{O}$ and $\mathrm{O}_{2}$ by the activation of CAT (Shamakhi et al., 2020). Thus, the lower activity of CAT in $A$. gossypii fed on plants inoculated with $B$. bassiana could result from the increased levels of flavonoids (Ahmad \& Pardini, 1990), alkaloids (Cai et al., 2009), and phenols (Lukasik, 2007) in these plants. Reduced CAT activity would diminish the ability of $A$. gossypii to overcome further dietary oxidative stress (Felton \& Duffey, 1991). Furthermore, the higher levels of phenols in fungus-treated plants could have resulted in increased APX activity in the aphids (Lukasik et al., 2009), possibly resulting in ascorbic acid deficiency, as APX oxidizes ascorbic acid to dehydro-ascorbic acid (Felton \& Summers, 1993).
Because ascorbic acid acts as a powerful antioxidant against dietary pro-oxidants (Mathews et al., 1997), any deficiency would cause additional physiological stress for the aphids. The increased PO activity in A. gossypii fed on fungus-inoculated plants could be related to the elevated levels of alkaloids (Cai et al., 2009) or phenols (GonzalezSantoyo \& Cordoba-Aguilar, 2012) in these plants. Ingestion of these secondary metabolites from host plants tends to increase PO activity in herbivorous insects, and typically results in production of cytotoxic quinones (Sugumaran et al., 2000). Overall, our results indicate that endophytic $B$. bassiana causes oxidative stress to $A$. gossypii by disrupting antioxidative processes, which likely contributes to the observed reductions in aphid fitness.

Because stress induces compensatory changes in organismal metabolism, energy reserves often reflect overall fitness and condition (Villarroel et al., 2009, Homayoonzadeh et al., 2020b). The reduced protein content of cotton aphids fed on $B$. bassiana-inoculated plants may reflect the observed reduction in enzyme content (Neoliya et al., 2005). Reduced lipid content may reflect increased secretion of the corpus allatum hormone in response to lipid release from the fat body and other tissues (Mandal, 1982), as well as activation of the adipokinetic hormone, which increases lipolysis activity in fat body adipocytes (Patel et al., 2005). In contrast, decreased glycogen content, coupled with increased levels of carbohydrate, may reflect increased glycogenolysis, the process which converts glycogen reserves to soluble carbohydrate (Lagadic et al., 1994). Reductions in these three primary energy reserves would be expected to negatively impact aphid fitness. However, the changes we observed in $A$. gossypii nutrient reserves on fungus-inoculated plants may also reflect reduced consumption due to changes in feeding behavior. For example, Gonzalez-Mas et al. (2019b) used the electrical penetration graph technique to confirm modified $A$. gossypii feeding behavior on $B$. bassiana-colonized melon plants that resulted in reduced acquisition of two cucurbit viruses.

In this study, the longevity and reproductive success of A. gossypii was diminished after aphids fed on fungus-inoculated plants, whether Naturalis ${ }^{\circledR}$-L or the B. bassiana isolate alone was used. Host plant antioxidant systems can directly impact herbivores, and higher levels of $\mathrm{H}_{2} \mathrm{O}_{2}$ often correlate negatively with their survival (Sohal, 1988). Strong negative correlations have been demonstrated between plant alkaloid content and herbivore growth, immature survival, reproduction, and longevity (Thakur et al., 2012). Likewise, high levels of plant phenols are also negatively correlated with the same indices of herbivore fitness (Wermelinger et al., 1991; Srjnwasaperumal et al., 1992), as are elevated levels of flavonoids (Salunke et al., 2005; Vasquez et al., 2008; Golan et al., 2017). Thus, we conclude that the altered host plant physiology induced by $B$. bassiana inoculation of cucumber plants reduced the fitness of cotton aphids and would be expected to diminish aphid abundance in the crop, above and beyond the mortality caused by direct exposure. In a natural situation, most apterous aphids will feed on a plant for much longer than 
the $24 \mathrm{~h}$ exposure period we tested, so the chronic effects of longer term exposure would likely produce even greater negative impacts on the aphid population.

The stress caused by feeding on B. bassiana-inoculated plants may also enhance $A$. gossypii management by increasing their susceptibility to insecticides. Aphids that fed on fungus-inoculated plants were significantly more susceptible to pirimicarb, likely due to reduced levels of the enzymes used to detoxify this pesticide (Liang et al., 2007; Liu et al., 2015). Consequently, inoculation of cucumber plants with $B$. bassiana could potentially aid in maintaining a higher level of insecticide susceptibility within the $A$. gossypii population, thus mitigating the evolution of resistance in the aphids (Ambethgar, 2009).

We conclude that inoculation of cucumber plants with $B$. bassiana elevates levels of secondary metabolites, which alter the physiology of cotton aphids that feed on them. Therefore, endophytic $B$. bassiana has the potential to alter herbivore-plant interactions in favor of cucumber plants, and at the expense of $A$. gossypii fitness and population growth. These findings reveal that endophyte-induced changes in plant physiology hold promise as a novel management tactic for diminishing populations of $A$. gossypii, while simultaneously enhancing their susceptibility to insecticides. Further research is warranted to explore the potential impact of endophytes on other cucumber pests, and on tritropic interactions within the cucumber arthropod community, but at this point the use of Naturalis ${ }^{\circledR}-\mathrm{L}$, a product readily available to farmers, can be recommended on early stage cucumber plants as a viable tactic for inclusion in an integrated management program for $A$. gossypii on greenhouse cucumber.

ACKNOWLEDGEMENT. This work was funded by the Research and Technology Deputy of the University of Tehran.

AUTHOR CONTRIBUTIONS. KT and HA conceived of the experiments and designed the study. $\mathrm{MH}$ and $\mathrm{ME}$ conducted the experiments. MH and JPM analyzed the data and wrote the paper, in consultation with SR.

CONFLICTS OF INTEREST. The authors declare no conflicts of interest.

\section{REFERENCES}

Ahmad S. \& Pardini R.S. 1990: Antioxidant defense of the cabbage looper, Trichoplusia ni: Enzymatic responses to the superoxide-generating flavonoid, quercetin, and photodynamic furanocoumarin, xanthotoxin. - Photochem. Photobiol. 51: 305-311.

Ambethgar V. 2009: Potential of entomopathogenic fungi in insecticide resistance management (IRM): a review. $-J$. Biopest. 2: 177-193.

Arnon D.I. 1949: Copper enzymes in isolated chloroplasts. Polyphenoloxidase in Beta vulgaris. - Plant Physiol. 24: 1-15.

Barbehenn R., Dukatz C., Holt C., Reese A., Martiskainen O., Salminen J.P., Yip L., Tran L. \& Constabel C.P. 2010: Feeding on poplar leaves by caterpillars potentiates foliar peroxidase action in their guts and increases plant resistance. - Oecologia 164: 993-1004.
Bi J. \& Felton G.W. 1995: Foliar oxidative stress and insect herbivory: primary compounds, secondary metabolites, and reactive oxygen species as components of induced resistance $-J$. Chem. Ecol. 21: 1511-1530.

Cai Q.N., Han Y., Cao Y.Z., Hu Y., Zhao X. \& Bi J.L. 2009: Detoxification of gramine by the cereal aphid Sitobion avenae. - J. Chem. Ecol. 35: 320-332.

Carletto J., Martin T., Vanlerberghe-Masutti F. \& Brévault T. 2010: Insecticide resistance traits differ among and within host races in Aphis gossypii. - Pest Man. Sci. 66: 301-307.

Croft H. \& Chen J. 2017: Leaf pigment content. In Liang S. (ed.): Comprehensive Remote Sensing. Elsevier, Amsterdam, pp. 1-26.

Degefu D.T., Yeshanew E.S. \& Gashawbeza G.T. 2014: Efficacy of dose-dependent indigenous microbial insecticides against cotton aphid, Aphis gossypii Glover (Homoptera: Aphididae) at various temperature regimes. - Int. J. Pest Manag. 60: 173-179.

Deguine J.P., Vaissayre M. \& Leclant F. 2017: IPM case studies: Cotton. In van Emden H.F. \& Harrington R. (eds): Aphids as Crop Pests. CABI, Wallingford, pp. 573-585.

Despres L., David J.P. \& Gallet C.M. 2007: The evolutionary ecology of insect resistance to plant chemicals. - Trends Ecol. Evol. 22: 298-307.

Ebert T. \& Cartwright B. 1997: Biology and ecology of Aphis gossypii Glover (Homoptera: Aphididae). — Southwest. Entomol. 22: 116-153.

Espinoza F., Vidal S., Rautenbach F., Lewu F. \& Nchu F. 2019: Effects of Beauveria bassiana (Hypocreales) on plant growth and secondary metabolites of extracts of hydroponically cultivated chive (Allium schoenoprasum L.). - Heliyon 5: e03038, $6 \mathrm{pp}$.

Felton G. \& Summers C. 1993: Potential role of ascorbate oxidase as a plant defense protein against insect herbivory. $-J$. Chem. Ecol. 19: 1553-1568.

Felton G.W. \& Duffey S.S. 1991: Protective action of midgut catalase in lepidopteran larvae against oxidative plant defenses. - J. Chem. Ecol. 17: 1715-1732.

Foray V., Pelisson P.F., Bel-Venner M.C., Desouhant E., VenNer S., Menu F., Giron D. \& Rey B. 2012: A handbook for uncovering the complete energetic budget in insects: the van Handel's method (1985) revisited. - Physiol. Entomol. 37: 295-302.

Golan K., Sempruch C., Gorska-Drabik E., Czerniewicz P., Lagowska B., Kot I., Kmiec K., Magierowicz K. \& LeszcZYNSKI B. 2017: Accumulation of amino acids and phenolic compounds in biochemical plant responses to feeding of two different herbivorous arthropod pests. - Arth-Plant Inter. 11: 675-682.

Gonzalez-Mas N., Cuenca-Medina M., Gutierrez-Sanchez F. \& Quesada-Moraga E. 2019a: Bottom-up effects of endophytic Beauveria bassiana on multitrophic interactions between the cotton aphid, Aphis gossypii, and its natural enemies in melon. - J. Pest Sci. 92: 1271-1281.

Gonzalez-Mas N., Quesada-Moraga E., Plaza M., Fereres A. \& Moreno A. 2019b: Changes in feeding behaviour are not related to the reduction in the transmission rate of plant viruses by Aphis gossypii (Homoptera: Aphididae) to melon plants colonized by Beauveria bassiana (Ascomycota: Hypocreales). - Biol. Control 130: 95-103.

Gonzalez-Mas N., Sanchez-Ortiz A., Valverde-Garcia P. \& Quesada-Moraga E. 2019c: Effects of endophytic entomopathogenic ascomycetes on the life-history traits of Aphis gossypii Glover and its interactions with melon plants. - Insects 10: $155,15 \mathrm{pp}$. 
Gonzalez-Santoyo I. \& Cordoba-Aguilar A. 2012: Phenoloxidase: a key component of the insect immune system. - Entomol. Exp. Appl. 142: 1-16.

GRAPHPAD 2019: Graphpad Prism ver. 8.2.0. GraphPad Software, La Jolla, CA, URL: https//www.graphpad.com.

Gurulingappa P., Sword G., Murdoch G. \& McGee P.A. 2010: Colonization of crop plants by fungal entomopathogens and their effects on two insect pests when in planta. - Biol. Control 55: 34-41.

Gurulingappa P., McGee P.A. \& Sword G. 2011: Endophytic Lecanicillium lecanii and Beauveria bassiana reduce the survival and fecundity of Aphis gossypii following contact with conidia and secondary metabolites. - Crop Prot. 30: 349-353.

Heidarvand L. \& Maali-Amiri R. 2013: Physio-biochemical and proteome analysis of chickpea in early phases of cold stress. J. Plant Physiol. 170: 459-469.

Homayoonzadeh M., Esmaeily M., Talebi K., Allahyari H., NoZARI J. \& MichaUd J.P. 2020a: Micronutrient fertilization of greenhouse cucumbers mitigates pirimicarb resistance in Aphis gossypii (Hemiptera: Aphididae). - J. Econ. Entomol. 113: 2864-2872.

Homayoonzadeh M., Moeini P., Talebi K., Allahyari H., Torabi E. \& Michaud J.P. 2020b: Physiological responses of plants and mites to salicylic acid improve the efficacy of spirodiclofen for controlling Tetranychus urticae (Acari: Tetranychidae) on greenhouse tomatoes. - Exp. Appl. Acarol. 82: 319-333.

Humber R.A. 1997: Fungi: Identification. In Lacey L.A. (ed.) Manual of Techniques in Insect Pathology. Academic Press, London, pp. 153-185.

JABER L.R. \& OwNLEY B.H. 2018: Can we use entomopathogenic fungi as endophytes for dual biological control of insect pests and plant pathogens? - Biol. Control 116: 36-45.

Johnson K.S. \& Felton G.W. 2001: Plant phenolics as dietary antioxidants for herbivorous insects: a test with genetically modified tobacco. - J. Chem. Ecol. 27: 2579-2597.

JuntheikKi M.R. \& Julkunen-Tiitto R. 2000: Inhibition of $\beta$-glucosidase and esterase by tannins from Betula, Salix, and Pinus species. - J. Chem. Ecol. 26: 1151-1165.

Kandil M.A., Abdallah I.S., Abou-Yousef H.M., Abdallah N.A. \& FouAd E.A. 2017: Mechanism of resistance to pirimicarb in the cowpea aphid Aphis craccivora. - Crop Prot. 94: $173-177$.

KanG M.A. \& Youn Y.N. 2008: The effects of controlling the Aphis gossypii Glover (Homoptera, Aphididae) on cucumber of entomopatoogenic fungus, Beauveria bassiana. - Kor. J. Agric. Sci. 35: 127-136.

Klieber J. \& Reineke A. 2015: The entomopathogen Beauveria bassiana has epiphytic and endophytic activity against the tomato leaf miner Tuta absoluta. — J. Appl. Entomol. 140: 580-589.

Lagadic L., CaQuet T. \& Ramade F. 1994: The role of biomarkers in environmental assessment (5). Invertebrate populations and communities. - Ecotoxicology 3: 193-208.

Liang P., CUI J.Z., Yang X.Q. \& GaO X.W. 2007: Effects of host plants on insecticide susceptibility and carboxylesterase activity in Bemisia tabaci biotype B and greenhouse whitefly, Trialeurodes vaporariorum. - Pest Man. Sci. 63: 365-371.

Liu B., Coy M., Wang J.J. \& Stelinski L.L. 2015: The effect of host plant species on the detoxifying enzymes of the Asian citrus psyllid, Diaphorina citri (Hemiptera: Liviidae). - Fla Entomol. 98: 997-999.

Loureiro E. DE S. \& Moino A. 2006: Pathogenicity of hyphomycete fungi hifomicetos to the aphids Aphis gossypii Glover and Myzus persicae (Sulzer) (Hemiptera: Aphididae). — Neotrop. Entomol. 35: 660-665 [in Portuguese, English abstract].
LUKASIK I. 2007: Changes in activity of superoxide dismutase and catalase within cereal aphids in response to plant o-dihydroxyphenols. - J. Appl. Entomol. 131: 209-214.

LUKASIK I. \& GoŁAWSKA S. 2007: Activity of Se-independent glutathione peroxidase and glutathione reductase within cereal aphid tissues. - Biol. Lett. 4: 31-39.

LuKasik I., GoŁawska S. \& Wojcicka A. 2009: Antioxidant defense mechanisms of cereal aphids based on ascorbate and ascorbate peroxidase. - Biologia 64: 994-998.

MANDAL D. 1982: Effect of juvenoid and allatectomy on the biochemical components of gonads in Gryllotalpa gryllotalpa (Gryllotalpidae: Orthoptera: Insecta). - Proc. Indian Nat. Sci. Acad. 48: 486-492.

Mardani-Talaee M., Zibaee A., Nouri-Ganblani G. \& Razmuou J. 2016: Chemical and organic fertilizers affect physiological performance and antioxidant activities in Myzus persicae (Hemiptera: Aphididae). - Invert. Surv. J. 13: 122-133.

Mathews M.C., Summers C.B. \& Felton G.W. 1997: Ascorbate peroxidase: a novel antioxidant enzyme in insects. - Arch. Insect Biochem. Physiol. 34: 57-68.

McKinnon A.C., SaAri S., Moran-Diez M.E., Meyling N.V., RaAD M. \& Glare T.R. 2017: Beauveria bassiana as an endophyte: A critical review on associated methodology and bicontrol potential. - BioControl 62: 1-17.

McKinnon A.C., Glare T.R., Ridgway H.J., Mendoza-Mendoza A., Holyoake A., Godsoe W.K. \& Bufford J.L. 2018: Detection of the entomopathogenic fungus Beauveria bassiana in the rhizosphere of wound-stressed Zea mays plants. - Fron. Micriobiol. 9: 1161, 16 pp.

Meena H., Hnamte S. \& Siddhardha B. 2019: Secondary metabolites from endophytic fungi: chemical diversity and application. In Singh B.P. (ed.): Advances in Endophytic Fungal Research: Present Status and Future Challenges. Springer International Publishing, Cham, pp. 145-169.

Moloinyane S. \& NChu F. 2019: The effects of endophytic Beauveria bassiana inoculation on infestation level of Planococcus ficus, growth and volatile constituents of potted greenhouse grapevine (Vitis vinifera L.). - Toxins 11: 72, 13 pp.

Moores G.D., Gao X., Denholm I. \& Devonshire A.L. 1996: Characterisation of insensitive acetylcholinesterase in insecticide-resistant cotton aphids, Aphis gossypii Glover (Homoptera: Aphididae). - Pest Biochem. Physiol. 56: 102-110.

Neoliya N.K., Singh D. \& Sangawan R.S. 2005: Azadirachtin influences total head protein content of Helicoverpa armigera Hub. larvae. - Curr. Sci. 88: 1889-1890.

Ownley B.H., Griffin M.R., Klingeman W.E., Gwinn K.D., Moulton J.K. \& Pereira R.M. 2008: Beauveria bassiana: Endophytic colonization and plant disease control. $-J$. Invert. Pathol. 98: 267-270.

Patel R.T., Soulages J.L., Hariharasundaram B. \& Arrese E.L. 2005: Activation of the lipid droplet controls the rate of lipolysis of triglycerides in the insect fat body. - J. Biol. Chem. 280: 22624-22631.

Polo 2007: Polo plus, Ver. 2.0. LeOra Software Company, Petaluma, CA, https://www.leora-software.com.

Posada F., Aime M.C., Peterson S.W., Rehner S.A. \& Vega F.E. 2007: Inoculation of coffee plants with the fungal entomopathogen Beauveria bassiana (Ascomycota: Hypocreales). Mycol. Res. 111: 748-757.

Rajashekar Y., RaghaVendRa A. \& BakthaVatsalam N. 2014: Acetylcholinesterase inhibition by biofumigant (Coumaran) from leaves of Lantana camara in stored grain and household insect pests. — BioMed Res. Inter. 2014: 187019, 6 pp. 
Robertson J.L., Jones M.M., Olguin E. \& Alberts B. 2017: Bioassays with Arthropods, 3rd ed. CRC Press, Taylor and Francis, Boca Raton, FL, 212 pp.

Rondot Y. \& ReINEKE A. 2018: Endophytic Beauveria bassiana in grapevine Vitis vinifera (L.) reduces infestation with piercingsucking insects. - Biol. Control 116: 82-89.

Salunke B.K., KotKar H.M., MendKi P.S., Upasani S.M. \& MAHESHWARI V.L. 2005: Efficacy of flavonoids in controlling Callosobruchus chinensis (L.) (Coleoptera: Bruchidae), a postharvest pest of grain legumes. - Crop Prot. 24: 888-893.

Sanchez-Rodríguez A.R., del Campillo M.C. \& Quesada-MoraGA E. 2015: Beauveria bassiana: An entomopathogenic fungus alleviates $\mathrm{Fe}$ chlorosis symptoms in plants grown on calcareous substrates. - Scientia Hort. 197: 193-202.

Sanchez-Rodríguez A.R., Raya-Diaz S., Zamarreno A.M., Garcia-Mina J.M., del Campillo M.C. \& Quesada-Moraga E. 2018: An endophytic Beauveria bassiana strain increases spike production in bread and durum wheat plants and effectively controls cotton leafworm (Spodoptera littoralis) larvae. - Biol. Control 116: 90-102.

Shamakhi L., Zibaee A., Karimi-Malati A. \& Hoda H. 2020: Simultaneous effects of thermal stress and fungal infection on lipid peroxidation and antioxidant system of rice-striped stem borer, Chilo suppressalis Walker (Lepidoptera: Crambidae). Biol. Rhythm Res. 51: 225-237.

SinClaIR B.J. 2015: Linking energetics and overwintering in temperate insects. - J. Therm. Biol. 54: 5-11.

Singh D., Kesavan A.K. \& Sohal S.K. 2019: Exploration of antiinsect potential of trypsin inhibitor purified from seeds of Sapindus mukorossi against Bactrocera cucurbitae. - Sci. Rep. 9: $1-14$.

SoHAL R. 1988: Effect of hydrogen peroxide administration on life span, superoxide dismutase, catalase, and glutathione in the adult housefly, Musca domestica. - Exp. Gerontol. 23: 211-216.

Srjnwasaperumal S., Samuthiravelu P. \& Muthukrishnan J. 1992: Host plant preference and life table of Megacopta cribraria (Fab.) (Hemiptera: Plataspidae). — Proc. Indian Nat. Sci. Acad. 6: 333-340.

Sugumaran M., Nellaiappan K. \& Valivittan K. 2000: A new mechanism for the control of phenoloxidase activity: inhibition and complex formation with quinone isomerase. - Arch. Biochem. Biophys. 379: 252-260.

Sunkar R., Kapoor A. \& ZhU J.K. 2006: Posttranscriptional induction of two $\mathrm{Cu} / \mathrm{Zn}$ superoxide dismutase genes in Arabidopsis is mediated by downregulation of miR398 and important for oxidative stress tolerance. - Plant Cell 18: 2051-2065.

Thakur A., Kaur S., Kaur A. \& Singh V. 2012: Detrimental effects of endophytic fungus Nigrospora sp. on survival and de- velopment of Spodoptera litura. - Biocon. Sci. Technol. 22: 151-161.

Vasquez C., Aponte O., Morales J., Sanabria M.E. \& Garcia G. 2008: Biological studies of Oligonychus punicae (Acari: Tetranychidae) on grapevine cultivars. - Exp. Appl. Acarol. 45: 59-69.

VEGA F.E. 2018: The use of fungal entomopathogens as endophytes in biological control: a review. - Mycologia 110: 4-30.

Velikova V., Yordanov I. \& EDREVA A. 2000: Oxidative stress and some antioxidant systems in acid rain-treated bean plants: protective role of exogenous polyamines. - Plant Sci. 151: $59-66$.

Villarroel M.J., Sancho E., Andreu-Moliner E. \& Ferrando M.D. 2009: Biochemical stress response in tetradifon exposed Daphnia magna and its relationship to individual growth and reproduction. - Sci. Tot. Environ. 407: 5537-5542.

Wang K.Y., Guo Q.L., XIA X.M., Wang H.Y. \& Liu T.X. 2007: Resistance of Aphis gossypii (Homoptera: Aphididae) to selected insecticides on cotton from five cotton production regions in Shandong, China. - J. Pest. Sci. 32: 372-378.

Wang Z., Zhao Z., Cheng X., Liu S., Wei Q. \& Scott I.M. 2016: Conifer flavonoid compounds inhibit detoxification enzymes and synergize insecticides. - Pest. Biochem. Physiol. 127: $1-7$.

War A.R., Paulraj M.G., Ahmad T., Buhroo A.A., Hussain B., Ignacimuthu S. \& Sharma H.C. 2012: Mechanisms of plant defense against insect herbivores. - Plant Signal. Behav. 7: $1306-1320$.

Wermelinger B., Oertli J.J. \& Baumgartner J. 1991: Environmental factors affecting the life-tables of Tetranychus urticae (Acari: Tetranychidae) III. Host-plant nutrition. - Exp. Appl. Acarol. 12: 259-274.

Wink M., Schmeller T. \& Latz-Bruning B. 1998: Modes of action of allelochemical alkaloids: interaction with neuroreceptors, DNA, and other molecular targets. - J. Chem. Ecol. 24: 1881-1937.

Wu K., Zhang J., Zhang Q., Zhu S., Shao Q., Clark K.D., Liu Y. \& Ling E. 2015: Plant phenolics are detoxified by prophenoloxidase in the insect gut. - Sci. Rep. 5: 16823, 15 pp.

Yu S. \& ABo-Elghar G. 2000: Allelochemicals as inhibitors of glutathione S-transferases in the fall armyworm. - Pest. Biochem. Physiol. 68: 173-183.

Zahedi A., Razmjou J., Rafiee-Dastjerdi H., Leppla N.C., Golizadeh A., Hassanpour M. \& Ebadollahi A. 2019: Tritrophic interactions of cucumber cultivar, Aphis gossypii (Hemiptera: Aphididae), and its predator Hippodamia variegata (Coleoptera: Coccinellidae). — J. Econ. Entomol. 112: 1774-1779.

Received June 8, 2021; revised and accepted December 23, 2021 Published online January 7, 2022 